DOI: 10.17117/na.2016.12.01.331

Поступила (Received): 29.12.2016

\title{
Верведа В.В.
}

\section{Соотношение вещно-правовых и обязательственно правовых способов защиты вещных прав}

\author{
Verveda V.V. \\ Ratio proprietary and obyazatelstvenno legal \\ ways of protection of the real rights
}

В статье рассмотрены различные точки зрения известных ученых относительно конкуренции вещно-правовых и обязательственно-правовых исков. Автор рассматривает проблему соотношения исков с субъективной и объективной стороны, а также в данной работе приводятся критерии разграничения вещно-правовых и обязательственно-правовых исков, позволяющие правильно квалифицировать требования истца для определения надлежащего способа защиты нарушенных прав

Ключевые слова: вещно-правовой иск, обязательственно-правовой иск, конкуренция исков

\section{Верведа Виктория Викторовна}

Магистрант

Ростовский государственный экономический университет

г. Ростов-на-Дону, ул. Большая Садовая, 69
In article various points of view of the famous scientists concerning the competition of proprietary and obligations and legal claims are considered. The author considers a problem of a ratio of claims from the subjective and objective party, and also the criteria of differentiation of proprietary and obligations and legal claims allowing to qualify correctly requirements of the claimant for determination of a proper method of protection of the violated rights are given in this work

Key words: proprietary claim, obligations and legal claim, competition of claims

\author{
Verveda Viktoria Viktorovna \\ Master \\ Rostov state economic university \\ Rostov-on-Don, Bolshaya Sadovaya st., 69
}

В результате сближения вещных и обязательственных правоотношений возникла проблема так называемой конкуренции вещно-правовых и обязательственно-правовых исков.

По данному вопросу уже в 1950-70 гг. велась оживленная теоретическая дискуссия. Одна сторона, наиболее ярко представленная М. В. Зимелевой, выступала за признание допустимости конкуренции виндикационного и договорного исков. Иную позицию занимали, например, А. Н. Арзамасцев, Р. О. Халфина, Д. М. Генкин, К. А. Граве, Ю. К. Толстой, В. А. Рясенцев, полагавшие, что решающее значение имеют иски, вытекающие из обязательственных правоотношений. Промежуточной позиции придерживался О. С. Иоффе, допускавший конкуренцию указанных исков, но лишь при определенных условиях. Отрицая при наличии договорных отношений возможность выбора по инициативе истца между 
договорным и виндикационным требованиями, О. С. Иоффе на примере судебной практики по договору хранения показывал, что виндикационный иск можно применить и доказать факт принадлежности спорного имущества истцу на праве собственности лишь тогда, когда ответчик-хранитель отрицает сам факт заключения договора с истцом и последний не может привести доказательства в подтверждение существования договорного правоотношения между сторонами [2, с. 130].

Существуют и более необычные точки зрения на вопрос конкуренции вещных и обязательственных исков. Так, А. В. Коновалов отрицает конкуренцию виндикационного иска и иска из договора, но допускает возможность конкуренции негаторного иска с требованием, основанным на договоре [3, с. 156]. С таким допущением конкуренции исков, основанном на придании искусственной универсальности негаторному иску, трудно согласиться.

Проблему соотношения исков и выбора надлежащего способа защиты нужно рассматривать в двух ракурсах: объективно и субъективно. Так, если использовать субъективный подход, необходимо учитывать общую диспозитивность гражданско-правового регулирования, а также нормы гражданского законодательства, предусматривающие, что физические и юридические лица осуществляют свои гражданские права своей волей и в своем интересе [1, ст. 1], по своему усмотрению [1, ст. 9]. Указанные положения не запрещают субъекту вещного права осуществлять свое право на защиту по своему усмотрению [1, ст. 12]. Объективно же необходимо учитывать правовую природу вещных прав, и , соответственно, присущую им абсолютную защиту, а также динамику вещных правоотношений. Это дает возможность не ставить применение вещно-правовых способов защиты в зависимость от наличия или отсутствия обязательственных правоотношений между сторонами [4, с. 136].

К общим критериям соотношения вещных и обязательственных исков, которые позволяют провести разграничение можно отнести следующие [4, с. 137].

1. Основание требования;

2. Предмет спора по иску;

3. Свойства предмета спора;

4. Направленность требования;

5. Способ нарушения или оспаривания права;

6. Правоотношение опосредующее применения иска;

7. Следование права на иск;

В заключении следует отметить, что конкуренция вещных и обязательственных исков недопустима, поскольку правовое значение имеет лишь вопрос о соотношении указанных способов защиты. Разграничение вещных и обязательственных исков должно проводиться исходя из рассмотренных выше критериев, которые в своем единстве позволят правильно квалифицировать требования истца для определения надлежащего способа защиты нарушенных прав.

\section{Список используемых источников:}

1. Гражданского кодекса Российской Федеращии от 30 ноября 1994 г. N 51-ФЗ (с изм. и доп., вступившими в силу с 3 июля 2016 г. N 354-ФЗ) // Собрание законодательства Российской Федерации от 5 декабря 2016 г. $\mathrm{N} 32 \mathrm{~cm} .3301$. 
2. Братусь М.Б. О соотношении (конкуренции) вещно-правовых и обязательственно-правовых способов защиты права собственности // Журнал российского права. 2005. № 6 (102). С. 128-134.

3. Коновалов, А. В. Владение и владельческая защита в гражданском праве. СПб.: Юрид. центр Пресс, 2002. $299 \mathrm{c}$.

4. Подшивалов Т.П. Соотношение и конкуренция вещных и обязательственных исков // Актуальные проблемы гражданского права. 2015. № 1 (5). С. 135-148.

(C) 2016, Верведа В.В.

Соотношение вещно-правовых и обязательственно правовых способов защиты вещных прав
(C) 2016, Verveda V.V.

Ratio proprietary and obyazatelstvenno legal ways of protection of the real rights 